\title{
A temporary biological dressing in the treatment of varicose ulcers and skin defects
}

\author{
A. V. KaISARY \\ F.R.C.S.
}

The Royal London Homoeopathic Hospital, Great Ormond Street, London WCI

\begin{abstract}
Summary
Corethium 2 has been known to be a valuable biological dressing which encourages re-epithelization in cases of tissue loss, especially in varicose ulcers. It ensures a superior quality of healed tissue even in difficult chronic cases. It also reduces the overall treatment time and can be used as an out-patient dressing.
\end{abstract}

\section{Introduction}

One of the known complications of varicose veins is varicose leg ulcer for which different methods of treatment have been tried, for example, bed rest (Ferguson and Logan, 1961), compression and topical medicaments (Haeger, 1964), compression and ambulation, and vertical leg drainage (Bourne, 1974) (Table 1).

In the early months of 1974 a biological dressing consisting of lyophilized porcine skin epidermis was marketed for the topical treatment of burn injuries. During its manufacture, a companion material was discovered. This new material is a fine, elastic, almost translucent tissue of a single layer of dermal collagen which can be reconstituted from the freeze-dried state in under $5 \mathrm{~min}$. It is prepared as a layer of porcine dermal collagen $\mathbf{0 . 3} \mathrm{mm}$ thick, carefully freeze-dried and sterilized by $\gamma$-irradiation. It is supplied in different convenient sizes.

Because of the success in healing varicose ulcers, the author was encouraged to use Corethium 2 in the treatment of other conditions in which there was skin loss. In all of these healing was rapid and complete.

\section{Dressing technique}

The method of dressing was as follows. The supplied outer over-wrap of the Corethium 2 dressing was opened and, using the correct aseptic technique, the inner over-wrap was peeled apart and the Corethium 2 was dispensed into a large bowl containing sterile isotonic saline at room temperature. The dressing took $5 \mathrm{~min}$ to reconstitute. During reconstitution the old dressing was removed and the skin defect or ulcer area cleaned with isotonic saline. No other lotions, antiseptics or desloughing agents were used. The edges of the reconstituted Corethium 2 were trimmed to fit closely to the contours of the area of tissue loss. The Corethium 2 was covered with a layer of Jelonet (Sofra-Tulle), then with a paste bandage (Viscopaste PB7-10\% zinc paste) and then with a crepe bandage, and lastly a Tubigrip layer. The dressing was applied from the cleft of the toes to the tibial tubercle.

The Corethium 2 was changed at 4 days initially, then weekly. This technique was continued, adjusting the size of Corethium 2, until healing was completed.

All the patients were treated as out-patients, but four cases of the varicose ulcer groups were treated by vertical drainage in hospital in the first week of treatment as they presented with grossly swollen, oedematous legs. The postoperative skin loss cases? were allowed home after they had made a satiszo factory recovery, and their dressings were also done? in the out-patient department.

One patient had an ischaemic ulcer and was in hospital for definitive treatment of his vascular occlusion disease.

\section{Clinical results (Tables $1-3$ )}

All the varicose ulcers treated by this method healed completely $(100 \%)$, and were followed-up for 6 months with no recurrence. The patients were advised to continue to wear an elastic stocking support indefinitely.

The rate of healing of the ulcers proved to be faster than those treated by other conventional methods. The effects produced by the dressing were dramatic_pain relief was immediate. The patients were keen to continue this treatment, although in four cases excessive ooze was noticed in the first 2 to 3 weeks, but this cleared eventually.

As it had proved so successful in the treatment of varicose ulcers, the author was encouraged to use this dressing in the treatment of other conditions associated with skin loss, including leg eczema with ulcers, burns, ischaemia, subcutaneous calcinosis of unknown cause, and postoperative skin necrosis. All the cases treated healed remarkably iwell. 
TABLE 1. Rate of healing of leg ulcers with various methods of treatment

\begin{tabular}{|c|c|c|c|c|c|}
\hline \multirow[b]{2}{*}{ Series } & \multirow[b]{2}{*}{ Treatment } & \multirow{2}{*}{$\begin{array}{c}\text { No. } \\
\text { of } \\
\text { cases }\end{array}$} & \multirow{2}{*}{$\begin{array}{c}\text { Mean size } \\
\text { of ulcers } \\
\left(\mathrm{mm}^{2}\right)\end{array}$} & \multicolumn{2}{|c|}{ Mean rate of healing } \\
\hline & & & & $\mathrm{mm}^{2} /$ week & $\mathrm{mm}^{2} /$ day \\
\hline $\begin{array}{l}\text { Fergusson \& } \\
\text { Logan (1961) }\end{array}$ & Bed rest & 271 & - & $27 \cdot 5$ & $3 \cdot 9$ \\
\hline Haeger (1964) & $\begin{array}{l}\text { Compression and } \\
\text { topical medicaments }\end{array}$ & 91 & 545 & 56 & 8 \\
\hline Bourne (1974) & $\begin{array}{l}\text { Vertical leg } \\
\text { drainage }\end{array}$ & 106 & 545 & 55 & $6 \cdot 8$ \\
\hline Rundle, Cameron & Bisgaard & 8 & 1290 & 90 & 13 \\
\hline (1976) & Porcine dermis & 6 & 1720 & 180 & 26 \\
\hline
\end{tabular}

TABLE 2. Rate of healing of leg ulcers and skin defects of different aetiologies treated by porcine skin (dermis)

\begin{tabular}{lcccccc}
\hline $\begin{array}{c}\text { Aetiology of } \\
\text { skin defect }\end{array}$ & $\begin{array}{c}\text { No. of } \\
\text { cases }\end{array}$ & $\begin{array}{c}\text { Mean size } \\
\text { of ulcers } \\
\left(\mathrm{mm}^{2}\right)\end{array}$ & $\begin{array}{c}\text { Mean duration } \\
\text { of treatment } \\
\text { (weeks) }\end{array}$ & \multicolumn{2}{c}{ Rate of healing } \\
\cline { 6 - 7 } & 18 & 940 & $5 \cdot 1$ & 172 & 25 \\
$\mathrm{~mm}^{2} /$ week & $\mathrm{mm}^{2} / \mathrm{day}$ \\
\hline Varicose ulcer & 6 & 543 & $3 \cdot 5$ & 148 & 21 \\
Skin eczema & 5 & 619 & $4 \cdot 4$ & 137 & 20 \\
Postoperative & 1 & 25000 & $12 \cdot 0$ & 2083 & 298 \\
Burn 3 & 1 & 2344 & $8 \cdot 0$ & 293 & 42 \\
Subcutaneous calcinosis & 1 & 1964 & $4 \cdot 0$ & 491 & 70 \\
Ischaemic & &
\end{tabular}

Total number treated, 32 cases; result of treatment, all cases completely healed $(100 \%)$.

TABLE 3. Study of 1000 cases of varicose veins treated in the Royal London Homoeopathic Hospital (1965-75)

\begin{tabular}{ccccc}
\hline $\begin{array}{c}\text { No. of } \\
\text { varicose } \\
\text { ulcers }\end{array}$ & $\begin{array}{c}\text { Mean } \\
\text { size }\end{array}$ & $\begin{array}{c}\text { Mean duration } \\
\text { of treatment } \\
\text { (weeks) }\end{array}$ & $\begin{array}{c}\text { Healed } \\
\text { ulcers }\end{array}$ & Failures \\
\hline 117 & - & $18 \cdot 3$ & 103 & 14 \\
\hline
\end{tabular}

Methods of treatment: local medicaments, Bisgaard. All patients started treatment as in-patients (mean stay in hospital $20 \cdot 3$ days).

\section{Conclusion}

Corethium 2 (sterilized lyophilized porcine skin dermis) is found to be an effective treatment of varicose ulcers and other conditions associated with skin loss. The increased rate of healing, symptomatic relief of the patient, the good quality of the new skin formed and its being suitable for outpatient treatment, recommends its use.

\section{Acknowledgments}

I am grateful to Mr M. D. Staunton, Mr G. S. Ramsay, Consultant Surgeons, and $\mathrm{Mr}$ D. Churchill-Davidson, Consultant Orthopaedic Surgeon, at the Royal London Homoeopathic Hospital for permission to treat their patients with porcine skin. I would also like to thank Mr J. Hargraves from Ethicon Ltd for his help.

\section{References}

BOURNE, I.H.J. (1974) Vertical leg drainage of oedema in treatment of leg ulcers. British Medical Journal, 2, 581.

Fergusson, A.G. \& LogaN, J.C.P. (1961) Leg ulcers: assessment of response to certain topical medicaments. British Medical Journal, 1, 871.

HAEger, K. (1964) Topical treatment of venous ulcers of leg Acta chirurgica scandinavica, 128, 140.

Rundle, J.S.H., Cameron, S.H. \& Ruckley, C.V. (1976) New porcine dermis dressing for varicose and traumatic leg ulcers. British Medical Journal, 2, 216. 